\title{
Maternal Diabetes Mellitus, a Rat Model for Nonthyroidal Illness: Correction of Hypothyroxinemia with Thyroxine Treatment Does Not Improve Fetal Thyroid Hormone Status
}

\author{
ROSA CALVO, GABRIELLA MORREALE DE ESCOBAR, FRANCISCO ESCOBAR DEL REY, and \\ MARIA JESÚS OBREGÓN
}

\begin{abstract}
Maintenance of normal maternal thyroxinemia prevents severe triiodothyronine $\left(T_{3}\right)$ deficiency of the fetus with primary thyroid failure (1). We have studied whether thyroxine $\left(T_{4}\right)$ would also protect the fetal brain when maternal hypothyroxinemia is caused by nonthyroidal illnesses. We have used the streptozotocin-induced diabetes mellitus pregnant rat as a model of maternal nonthyroidal illness. We measured the effects of diabetes mellitus, and of correction of the ensuing maternal hypothyroxinemia with $T_{4}$ as compared to insulin, on maternal body weight, the outcome of pregnancy, glucose, insulin, $T_{4}, T_{3}$, reverse $T_{3}$, and thyrotropin levels in the maternal and fetal circulation, as well as $T_{4}$ and $T_{3}$ concentrations in tissues, and iodothyronine deiodinases in liver, lung, and brain. The diabetic mothers showed changes in thyroid hormone status typical of nonthyroidal illnesses. Thyroid hormone status of the fetuses was severely affected: the total $T_{4}$ and $T_{3}$ pools decreased to one-third of normal values. $T_{4}$ and $T_{3}$ concentrations in the fetal brain were lower than normal and the expected increase in $5^{\prime}$-deiodinase activity was not observed. Although insulin treatment avoided or mitigated these changes, the low cerebral $T_{3}$ did not improve with $T_{4}$ treatment of the maternal hypothyroxinemia. Several findings indicated that treatment of the severely ill dams with $\mathrm{T}_{4}$ was actually harmful for the outcome of pregnancy. These negative effects were observed without the expected increase in the maternal or fetal $T_{3}$ pools.
\end{abstract}

\section{INTRODUCTION}

$\mathrm{T}$ HYroxine (T4) and 3,5,3'-triiodothyronine ( $\left.\mathrm{T}_{3}\right)$ concentrations are very low in all tissues of rat fetuses from dams with methimazole (MMI)-induced primary thyroid failure. If the maternal hypothyroxinemia is avoided by treatment with $\mathrm{T}_{4}$, the brain is preferentially protected against the deficiency of $T_{3}$ until birth (1): fetal brain $T_{3}$ reaches normal concentrations, despite lower than normal fetal serum $T_{4}$ and increased TSH levels. $T_{4}$ is by far the main source of cerebral $T_{3}$ in the rat fetus $(1,2)$; changes in circulating $T_{3}$ hardly affect cerebral $T_{3}$ within a physiological range of serum $T_{3}$ levels. Both the capacity of cerebral type II $5^{\prime}$-iodothyronine deiodinase ( $5^{\prime} \mathrm{D}$-II) to respond to low fetal serum $\mathrm{T}_{4}$ with a marked increase in its activity and the amount of $\mathrm{T}_{4}$ transferred from the mother to the fetus play crucial roles in maintaining $T_{3}$ homeostasis in the brain of the hypothyroid fetus. This protective ef- fect of the maternal $T_{4}$ would explain the lack of major brain damage of most hypothyroid fetuses at birth, in contrast with the irreversible central nervous system damage observed in the neurological cretin. The mother of the latter is severely hypothyroxinemic, and does not offer any protection to the fetal brain, which is therefore markedly $\mathrm{T}_{3}$ deficient before birth, despite the expected increase in $5^{\prime}$ D-II activity (3). Both in the neurological cretin (4) and in the experimental model of rats fed a diet with a very low iodine content (3), maternal circulating $T_{3}$ is normal, but this does not improve fetal brain $T_{3}$ concentrations unless the maternal hypothyroxinemia is also corrected.

These findings have drawn attention to the importance of maintaining normal maternal $\mathrm{T}_{4}$ levels during pregnancy, even when normal $T_{3}$ levels might prevent the appearance of clinical hypothyroidism. We already cautioned (1), however, against extrapolation of this conclusion to other situations where changes in maternal and fetal thy-

Unidad de Endocrinología Molecular, Instituto de Investigaciones Biomédicas, Consejo Superior de Investigaciones Científicas, and Facultad de Medicina, Universidad Autónoma de Madrid, Madrid, Spain. 
roid hormone status might not be due to primary thyroid failure or an inadequate iodine supply, but to other causes, such as "nonthyroidal" illness. This might interfere with the transfer of $\mathrm{T}_{4}$ from the mother to the fetus, the responses of fetal deiodinating enzymes, or other mechanism(s) contributing to fetal cerebral $\mathrm{T}_{3}$ homeostasis. Moreover, the possibility exists that treatment with $\mathrm{T}_{4}$ might actually be harmful in such conditions, as the decreased hormonal secretion by the thyroid is considered as a protective mechanism against energy loss and excessive catabolism (5-7).

Diabetes mellitus is considered as a nonthyroidal disease leading to alterations of thyroid hormone status typical of the so called "low $T_{3}$ syndrome" $(5-8)$. The major alterations in thyroid hormone economy are a reduction in the TSH stimulation of the thyroid gland, probably caused by "central" hypothyroidism, and in the peripheral generation of $\mathrm{T}_{3}$ from $\mathrm{T}_{4}(8)$. The injection of streptozotocin (STZ) in rats is frequently used to obtain an experimental model for the study of nonthyroidal illness, by inducing diabetes mellitus.

In the STZ-diabetic adult rat, as in other situations of nonthyroidal illness, both the thyroidal secretion of $\mathrm{T}_{4}$ and $T_{3}$ and the extrathyroidal monodeiodination of $T_{4}$ to $T_{3}$ are clearly impaired, as a consequence of which circulating $\mathrm{T}_{4}$ and $\mathrm{T}_{3}$ are very low, as well as the concentrations of both iodothyronines in most tissues (5-10). To our knowledge little is known about the possible influence of maternal diabetes on the thyroid hormone status of the fetus, except for a preliminary study from our group (11) showing that STZ-induced maternal diabetes mellitus also affects fetal thyroid hormone economy, causing a decrease of $T_{4}$ and $T_{3}$ in plasma and most fetal tissues, brain included, with possible impairment of the normal response of 5'D-II to low $\mathrm{T}_{4}$ concentrations. These alterations were mitigated or avoided by appropriate treatment of the dams with insulin.

The present study has been undertaken to assess the potential benefits for the fetus of the correction of maternal hypothyroxinemia when caused by nonthyroidal illness. The underlying cause of the maternal hypothyroxinemia might not be readily ascertained or treated, and treatment with $\mathrm{T}_{4}$ might be attempted to normalize maternal $\mathrm{T}_{4}$ levels, in view of the beneficial effects of this treatment for fetal brain $T_{3}$ in case of primary thyroid failure (1). Diabetes mellitus was used as a model of nonthyroidal illness. As will be seen, $\mathrm{T}_{4}$ treatment, without correction of the diabetic state, is of no benefit for fetal tissues, brain included, and actually appears to be harmful both for the mother and for the outcome of pregnancy.

\section{MATERIALS AND METHODS}

\section{Experimental design}

Female Wistar rats were used for this study. The guidelines for humane treatment of animals were followed in compliance with the principles outlined in "The care and use of animals" and the study was approved by the committee of our Institute. They were maintained at $22^{\circ} \mathrm{C}$ with 12-h periods of light and darkness and fed ad libitum with a standard diet (18 g protein, $39 \mathrm{~g}$ carbohydrate, $2.5 \mathrm{~g}$ lipid, and $4.5 \mathrm{~g}$ cellulose $/ 100 \mathrm{~g}$ plus salt and vitamin mixtures, with an estimated caloric content of $2.54 \mathrm{kcal} / \mathrm{g}$ ). They were mated with normal males and the morning of appearance of the vaginal plus was considered as day 0 of gestation. Twenty-four pregnant rats were divided into four groups. One group served as normal pregnant controls (C). At day 7 of gestation, the other three groups of rats (D groups) were injected into the femoral vein with $4.5 \mathrm{mg} / 100 \mathrm{~g}$ body weight (BW) of streptozotocin (STZ) dissolved in $50 \mathrm{mM}$ citrate buffer, $\mathrm{pH} 4.5$ (12). From the three groups of D rats, one was left without further treatment (D group), a second group was treated with insulin $(\mathrm{D}+\mathrm{Ins})$, and a third group with $\mathrm{T}_{4}\left(\mathrm{D}+\mathrm{T}_{4}\right)$. The group of $\mathrm{D}+$ Ins dams was injected sc once daily with $0.5 \mathrm{U}$ bovine insulin/100 $\mathrm{g} \mathrm{BW/day} \mathrm{from} 9$ to 20 days of gestation (dg). The group of $\mathrm{D}+\mathrm{T}_{4}$ dams was implanted under the dorsal skin with Alzet 2ML2 osmotic minipumps (Alza Co. Palo Alto, CA) delivering at a constant rate $2.4 \mu \mathrm{g} \mathrm{T}_{4} / 100$ g BW/day from 9 to $21 \mathrm{dg}$. The infusion of $\mathrm{T}_{4}$ was carried out as already described (1) with modifications: $\mathrm{T}_{4}$ (free acid form, Sigma Chemicals Co, St. Louis, MO) was dissolved in the minimum volume of $0.05 \mathrm{~N} \mathrm{NaOH}$ and then taken to the required volume in $50 \%$ propylene glycol.

At $21 \mathrm{dg}$ all dams were anesthetized with ether, bled, and perfused with $40-50 \mathrm{~mL}$ of $0.05 \mathrm{M}$ phosphosaline buffer, $\mathrm{pH} 7.4$, as described (1). Maternal plasma, liver, brain, heart, lung, and mamma were obtained and frozen. The uterus was dissected out and carefully rinsed and blotted free of maternal blood. The fetuses were then dissected out, bled, separated from the placenta, weighed, and immediately placed on ice. The fetal brain, liver, and lung were dissected out and quickly frozen on dry ice; the thyroid, adhering to the trachea, was withdrawn and frozen. The placentas were separated, weighed, and divided into the basal (maternal) and labyrinthine (fetal) sides with blunt forceps and frozen rapidly, as described $(1,13)$.

\section{Determination of thyroid hormone concentrations}

Thyroid hormones were determined by RIAs after extraction and purification of plasma and tissues (14-17). In brief, methanol is added to the still frozen tissue sample and homogenized with tracer amounts of $\left[{ }^{131} 1\right] \mathrm{T}_{4}$ and $\left[{ }^{125} \mathrm{I}\right] \mathrm{T}_{3}$ being added to each homogenate. This is followed by extraction of more than $90 \%$ of the endogenous and added iodothyronines using chloroform-methanol (2:1). The iodothyronines are then backextracted into an aqueous phase, and purified by passing this aqueous phase through Bio-Rad AG $1 \times 2$ resin columns. After a $\mathrm{pH}$ gradient, the iodothyronines are eluted with $70 \%$ acetic acid, which is then evaporated to dryness and dissolved in RIA buffer. Each extract is extensively counted to determine the recovery of the [ $\left.{ }^{131} \mathrm{I}\right] \mathrm{T}_{4}$ and $\left[{ }^{125} \mathrm{I}\right] \mathrm{T}_{3}$ added to each sample during the initial homogenization process. Average recovery is $50-60 \%$ for $\left[{ }^{131} \mathrm{I}\right] \mathrm{T}_{4}$ and $60-70 \%$ for $\left[{ }^{125} \mathrm{I}\right] \mathrm{T}_{3}$. The samples are submitted to highly sensitive RIAs for the determination of $\mathrm{T}_{4}$ and $\mathrm{T}_{3}$, the limits of sensitivity being 2.5 pg $\mathrm{T}_{4}$ and $1.5 \mathrm{pg} \mathrm{T}_{3} /$ tube. Each sample is processed in duplicate or triplicate at two or more dilutions. Concentrations are then calculated using the amounts of $T_{4}$ and $T_{3}$ found in the respective RIAs, the individual recovery of the 
[ ${ }^{131} \mathrm{I} \mathrm{T}_{4}$ and [ $\left.{ }^{125} \mathrm{I}\right] \mathrm{T}_{3}$ added to each sample during the initial homogenization process, and the weight of the tissue sample submitted to extraction.

Maternal samples were processed individually. Plasma from different fetuses were pooled to obtain $300-400 \mu \mathrm{L}$ aliquots. Fetal tissues were pooled ( 2 to 3 organs per pool) for the determination of $T_{4}$ and $T_{3}$. Pools were always obtained from fetuses of the same litter.

\section{Percentage of circulating "free" $T_{4}$ and $T_{3}$}

The method described by Mendel et al. (18) was used, with modifications. High specific activity $\left[{ }^{125} \mathrm{I}\right] \mathrm{T}_{4}$ or $\left[{ }^{125} \mathrm{I}_{\mathrm{T}} \mathrm{T}_{3}\right.$ (approximately $300,000 \mathrm{cpm}$ ) was added in a $5 \mu \mathrm{L}$ volume to $300 \mu \mathrm{L}$ of plasma, and incubated at room temperature for $1 \mathrm{~h}$. A $280-\mu \mathrm{L}$ aliquot of each was submitted to ultrafiltration using Microcon 10 microconcentrators (Amicon Division, W.R. Grace and Co, Beverly, MA) and a $20 \mathrm{~min}$ centrifugation at $14,000 \mathrm{rpm}$. A measured volume of each ultrafiltrate was added to $0.5 \mathrm{~mL}$ bovine serum and submitted to precipitation with $10 \%$ trichloroacetic acid (TCA) and centrifuged, the pellet being washed twice with the same solution of TCA. The washed pellet was counted and its radioactivity calculated as percentage of the initial added tracer, submitted to the same TCA precipitation and washing procedure. This percentage of "free" $\mathrm{T}_{4}$ $\left(\% \mathrm{FT}_{4}\right)$ or "free" $\mathrm{T}_{3}\left(\% \mathrm{FT}_{3}\right)$ and the $\mathrm{T}_{4}$ and $\mathrm{T}_{3}$ concentrations determined by RIA were used to calculate the concentrations of free $\mathrm{T}_{4}\left(\mathrm{FT}_{4}\right)$ or free $\mathrm{T}_{3}\left(\mathrm{FT}_{3}\right)$, respectively.

\section{Iodothyronine 5'- and 5-deiodinase activities}

Before each assay [ $\left.{ }^{125} \mathrm{I}\right] \mathrm{rT}_{3}\left(3,3^{\prime}, 5^{\prime}\right.$-triiodothyronine $)$ or $\left[{ }^{125} \mathrm{I}\right] \mathrm{T}_{4}$ was purified by paper electrophoresis to separate the iodide. Iodothyronine $5^{\prime}$-deiodinase $\left(5^{\prime} \mathrm{D}\right)$ activity was assayed as described $(17,19)$, using $2 \mathrm{mM}$ DTT and 400 or $200 \mathrm{nM} \mathrm{rT}_{3}$ for maternal and fetal liver, respectively, and $2 \mathrm{nM} \mathrm{rT}_{3}$ and $20 \mathrm{mM}$ DTT for maternal and fetal lung. Maternal and fetal brain 5'D-II activity was assayed $(2,19)$ using $2 \mathrm{nM} \mathrm{T}_{4}+1 \mu \mathrm{M} \mathrm{T}$ and $20 \mathrm{mM}$ DTT in the presence of $1 \mathrm{mM}$ 2-N-propyl-6-thiouracil (PTU). The ${ }_{125} \mathrm{I}^{-}$released was separated by ion exchange chromatography on Dowex- $50 \mathrm{~W}-\mathrm{X} 2$ columns equilibrated in $10 \%$ acetic acid. The production of equal amounts of iodide and $3^{\prime}, 3-\mathrm{T}_{2}$ was checked in some assays. The protein content was determined by the method of Lowry et al. (20), after precipitation of the homogenates with $10 \%$ TCA to avoid interferences from DTT in the colorimetric reaction.

\section{Other determinations}

$\mathrm{rT}_{3}$ concentrations in maternal and fetal plasma, and in placental extracts, were determined by RIA, as previously described $(13,21)$.

Maternal and fetal plasma glucose levels were determined by the glucose oxidase method (22) using 10-25 $\mu \mathrm{L}$ of plasma. Insulin levels in maternal and fetal plasma were measured using the specific RIA adapted for rat insulin with reagents supplied by Novo BioLabs (Denmark). We used rat insulin as standard, anti-porcine antiserum, and human ${ }^{125}$ I-labeled insulin as antigen.

TSH was determined in $200-\mu \mathrm{L}$ aliquots of maternal plasma using the immunoreactants for RIA kindly supplied by the National Institutes of Health (Bethesda, MD), and made available through the Rat Pituitary Agency of the National Institutes of Diabetes, Digestive and Kidney Diseases. Concentrations are expressed in weight equivalents of the rat TSH RP-3 reference preparation (23).

\section{Drugs and reagents}

$\mathrm{T}_{4}, \mathrm{~T}_{3}, 3,5$-diiodothyronine $\left(3,5-\mathrm{T}_{2}\right), \mathrm{PTU}$, and DTT were obtained from Sigma Chemical Co. (St. Louis, MO). $\mathrm{rT}_{3}$ and $3^{\prime}, 3-\mathrm{T}_{2}$ were obtained from Henning Berlin GMBH (Berlin, Germany).

High specific activity [ $\left.{ }^{131} \mathrm{I}\right] \mathrm{T}_{4},\left[{ }^{125} \mathrm{I}\right] \mathrm{T}_{3},\left[{ }^{125} \mathrm{I}\right] \mathrm{T}_{4}$, and $\left[{ }^{125} \mathrm{I}\right] \mathrm{rT}_{3}(3000 \mu \mathrm{Ci} / \mu \mathrm{g})$ were synthesized in our laboratory $(14,24)$ and used for highly sensitive $T_{4}, T_{3}$, and $r T_{3}$ RIAs, as recovery tracers for extraction, and as substrates for $5^{\prime}$ deiodinases.

\section{Statistical analysis}

After testing for homogeneity of variance using Bartlett's procedure, data were submitted to one-way analysis of variance. Square root or logarithmic transformations usually ensured homogeneity of variance when this was not achieved with the raw data. Significant differences among groups were assessed using the protected least significant difference (LSD) test. All statistical calculations were performed as described by Snedecor and Cochran (25). The $\mathrm{SE}$ appearing in the figures is the mean standard error calculated by ANOVA, and used for the identification of statistically significant differences between groups by the LSD test. For the sake of clarity, the $\pm \mathrm{SE}$ is shown in figures only on the $C$ value bar.

\section{RESULTS}

\section{Degree of maternal illness}

Figure 1 shows the insulin and glucose concentrations in the maternal plasma (M-plasma) from the different groups,

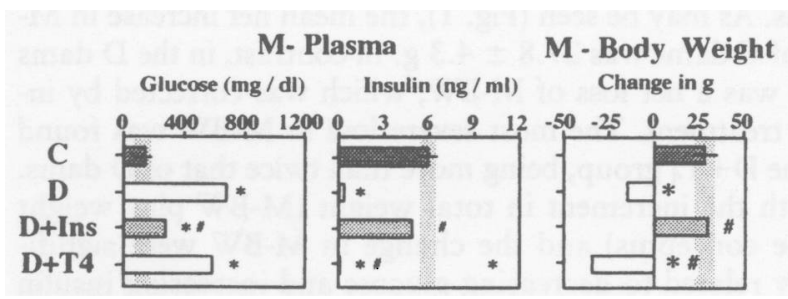

FIG. 1. Mean circulating insulin and glucose concentrations are shown for the dams from the different groups, as well as the calculated mean changes in the BW of the mother herself (M-BW) between 7 and 21 days of gestation, calculated as described in the Results section, by subtracting the weight of the conceptus from the total body weight. In this and the following figures, the $\mathrm{SE}$ shown only on the $\mathrm{C}$ value bar is the mean standard error calculated by ANOVA. The shaded area corresponds to the mean $C$ value $\pm S E$. An asterisk $\left(^{*}\right)$ identifies statistically significant differences versus $C$ dams; number sign (\#) identifies statistically significant differences versus the $\mathrm{D}$ group. Other statistically significant differences are not identified for the sake of clarity. 
Table 1. Mean ( \pm SEM) Increments in Total Body Weight (BW) between 7 and 21 Days of Gestation, Mean Number of Fetuses/ Dam, BW of Fetuses (F-BW), and Weights of the Placenta (Total, Maternal and Fetal Sides), at 21 Days of Gestation, of Normal (C) and Streptozotocin-Injected Dams (D), and of D Dams Treated with Insulin (D + INS), OR INFUSED WITH $\mathrm{T}_{4}\left(\mathrm{D}+\mathrm{T}_{4}\right)$

\begin{tabular}{lcccccc}
\hline Group & $\begin{array}{c}\text { Increment in } \\
\text { total weight }(g)\end{array}$ & $\begin{array}{c}\text { Number of } \\
\text { fetuses/dam }\end{array}$ & $\begin{array}{c}\text { F-body weight } \\
(\mathrm{mg})\end{array}$ & $\begin{array}{c}\text { Placental weight } \\
(\mathrm{mg})\end{array}$ & $\begin{array}{c}\text { M-placental } \\
\text { weight }(\mathrm{mg})\end{array}$ & $\begin{array}{c}F \text {-placental } \\
\text { weight }(\mathrm{mg})\end{array}$ \\
\hline $\mathrm{C}$ & $100.0 \pm 2.5$ & $12.4 \pm 1.0$ & $4872 \pm 32$ & $510.6 \pm 7.9$ & $154 \pm 9$ & $339 \pm 11$ \\
$\mathrm{D}$ & $31.6 \pm 8.8^{\mathrm{a}}$ & $10.0 \pm 1.3$ & $3196 \pm 66^{\mathrm{a}}$ & $568.1 \pm 122^{\mathrm{a}}$ & $116 \pm 4^{\mathrm{a}}$ & $361 \pm 11$ \\
$\mathrm{D}+\mathrm{Ins}$ & $71.3 \pm 10.6^{\mathrm{a}, \mathrm{b}}$ & $10.8 \pm 1.8$ & $4097 \pm 65^{\mathrm{a}, \mathrm{b}}$ & $531.2 \pm 14.6^{\mathrm{b}}$ & $136 \pm 5$ & $326 \pm 11$ \\
$\mathrm{D}+\mathrm{T}_{4}$ & $-11.3 \pm 3.8^{\mathrm{a}, \mathrm{b}}$ & $6.7 \pm 1.5^{\mathrm{a}}$ & $2746 \pm 92^{\mathrm{a}, \mathrm{b}}$ & $655.0 \pm 40.4^{\mathrm{a}, \mathrm{b}}$ & $165 \pm 28^{\mathrm{b}}$ & $432 \pm 66^{\mathrm{a}, \mathrm{b}}$ \\
\hline
\end{tabular}

a Statistically significant differences $(p<0.05)$ versus $C$ group.

bStatistically significant differences $(p<0.05)$ versus $D$ group.

at $21 \mathrm{dg}$. Circulating glucose levels were very high in the STZ-injected dams, which did not receive insulin, whether or not they were infused with $\mathrm{T}_{4}$. Insulin decreased significantly in the $\mathrm{D}$ dams; the infusion of $\mathrm{T}_{4}$ resulted in insulin levels that were even lower than those of $D$ dams. The injection of insulin affected both the insulin and glucose levels in the maternal circulation: Normal levels of insulin, as measured $24 \mathrm{~h}$ after the last injection, were found in the $\mathrm{D}+$ Ins group, with circulating glucose being somewhat higher than $\mathrm{C}$ values, although markedly decreased as compared to $\mathrm{D}$ animals.

Figure 1 also shows the calculated change in the body weight of the pregnant rats, free of the conceptus (M-BW), between 7 and $21 \mathrm{dg}$. The actual change of the dam plus conceptus appears in Table 1 , as well as the number of fetuses per litter and the body weights of the fetuses (F-BW). The weights of the total placenta, as well as those of the maternal side (M-Placenta) and fetal side (F-placenta) are also shown in Table 1 . The change in $\mathrm{M}-\mathrm{BW}$ was calculated by substracting the weight of the conceptus from the measured change in total weight. The weight of the conceptus was calculated for each animal from the sum of the weights of all the fetuses and placentas in each dam. Although extraembryonic fluids and membranes had not been collected, the sum of the fetal and placental weights appears to be a reasonable approximation to the total weight of the conceptus. As may be seen (Fig. 1), the mean net increase in $M$ $\mathrm{BW}$ of $\mathrm{C}$ dams was $27.8 \pm 4.3 \mathrm{~g}$. In contrast, in the $\mathrm{D}$ dams there was a net loss of M-BW, which was corrected by insulin treatment. The most severe loss in M-BW was found for the $\mathrm{D}+\mathrm{T}_{4}$ group, being more than twice that of $\mathrm{D}$ dams.

Both the increment in total weight $(\mathrm{M}-\mathrm{BW}$ plus weight of the conceptus) and the change in $\mathrm{M}-\mathrm{BW}$ were significantly related to decreasing glucose and increasing insulin concentrations in the maternal circulation, and appeared to be good indices of the degree of maternal illness. The closest fit was found for the change in $\mathrm{M}-\mathrm{BW}$ versus the logarithm of the M-plasma insulin levels $(n=24 ; r=0.76$, $p<0.001$ ).

\section{Effects of maternal illness on the outcome of pregnancy}

No reproductive abnormalities were observed in the control (C) group, whereas reabsorbed fetuses were found in many $\mathrm{D}$ dams. Treatment with insulin prevented these abnormalities, whereas they were most frequent in the $\mathrm{D}+\mathrm{T}_{4}$ dams. Either the number of fetuses per litter or the F-BW (or both) were decreased in the diabetic animals, the lowest number and $\mathrm{F}+\mathrm{BW}$ being found for the $\mathrm{D}+\mathrm{T}_{4}$ group. Treatment with insulin increased F-BW, but normal weights were not achieved. Observed changes in placental weights caused by the maternal diabetic state were greatest in the $\mathrm{D}+\mathrm{T}_{4}$ dams.

In summary, the outcome of pregnancy was affected by the maternal diabetic state and illness. This was prevented, or at least ameliorated, with the administration of $0.5 \mathrm{U}$ of insulin $/ 100 \mathrm{~g} \mathrm{BW} /$ day, and was actually worsened by the infusion of $\mathrm{T}_{4}(2.4 \mu \mathrm{g} / 100 \mathrm{~g} \mathrm{BW}$ per day $)$ into the $\mathrm{D}$ dams.

\section{Effects on thyroid hormone status of the mothers}

The concentrations of $\mathrm{T}_{4}, \mathrm{~T}_{3}, \mathrm{rT}_{3}$, and TSH in the maternal plasma are shown in Figure 2, as well as the circulating $\% \mathrm{FT}_{4}, \mathrm{FT}_{4}, \% \mathrm{FT}_{3}$, and $\mathrm{FT}_{3}$. Figure 3 shows the concentrations of $T_{4}$ and $T_{3}$ in the liver, lung, brain, heart, and mammary tissue.

Mean concentrations of $T_{4}, T_{3}$, and $\mathrm{rT}_{3}$ in the maternal circulation and of $\mathrm{T}_{4}$ and $\mathrm{T}_{3}$ in most tissues studied (Figs. 2 and 3 ) were lower in the D dams as compared to the $C$ mothers, the differences being statistically significant except for $\mathrm{M}$-brain $\mathrm{T}_{4}$ and $\mathrm{M}$-mamma $\mathrm{T}_{3}$. Circulating $\mathrm{TSH}$ (Fig. 2) was also lower in the $\mathrm{D}$ animals.

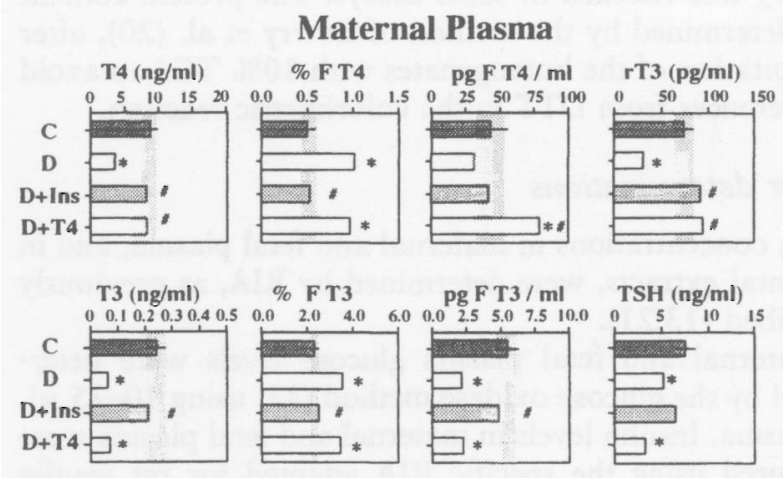

FIG. 2. The mean concentrations of $\mathrm{T}_{4}, \% \mathrm{FT}_{4}$, and $\mathrm{F} \mathrm{T}_{4}$, $\mathrm{T}_{3}, \% \mathrm{FT}_{3}$, and $\mathrm{F} \mathrm{T}_{3}$, as well as $\mathrm{rT}_{3}$ and $\mathrm{TSH}$ in the maternal circulation are shown for the different groups of dams. See the legend to Figure 1 for the meaning of the shaded area and of the asterisk and \#. 


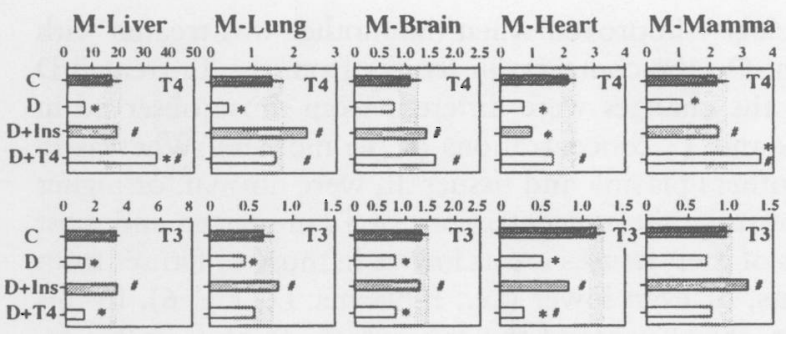

FIG. 3. The upper panels show the concentrations of $T_{4}$ in liver, lung, brain, heart, and mamma of the dams and the bottom panels the corresponding $\mathrm{T}_{3}$ concentrations, given in $\mathrm{ng} / \mathrm{g}$.

The circulating $\% \mathrm{FT}_{4}$ was increased in the diabetic dams (Fig. 2) to twice normal values of the normal pregnant dams. This increase was comparable to the decrease in total circulating $T_{4}$, as a result of which the mean total amount of circulating $\mathrm{FT}_{4}$, although lower in $\mathrm{D}$ as compared to $\mathrm{C}$ dams, was not statistically different from that of the $\mathrm{C}$ mothers. The \% $\mathrm{FT}_{3}$ also increased in $\mathrm{D}$ as compared to $C$ dams, but not to the extent that it could compensate for the decrease in circulating total $\mathrm{T}_{3}$, and the $\mathrm{FT}_{3}$ concentration was lower than that of $\mathrm{C}$ dams.

Treatment with insulin resulted in normal circulating $\mathrm{T}_{4}$, $\mathrm{T}_{3}, \mathrm{rT}_{3}$, and $\mathrm{TSH}$ concentrations, and normal $\% \mathrm{FT}_{4}, \mathrm{FT}_{4}$, $\% \mathrm{FT}_{3}$, and $\mathrm{FT}_{3}$. Thus, the maternal hypothyroxinemia caused by the diabetic state was avoided in the insulintreated $\mathrm{D}$ dams. Treatment with insulin also reversed the effects of the diabetic state on the concentrations of $T_{4}$ and $T_{3}$ in maternal tissues, with the exception of cardiac $T_{4}$.

The amount of $\mathrm{T}_{4}$ infused into the $\mathrm{D}$ rats effectively prevented maternal hypothyroxinemia near term (Fig. 2). As the $\% \mathrm{FT}_{4}$ was markedly increased by the uncorrected diabetic state, the $\mathrm{FT}_{4}$ levels actually increased 2-fold as compared to normal $\mathrm{C}$ rats. When the marked decrease in available $T_{4}$ of the $D$ dams was avoided by the infusion of $T_{4}$, circulating $\mathrm{rT}_{3}$ concentrations also increased to normal values and the $\mathrm{rT}_{3} / \mathrm{T}_{3}$ ratio increased 3-fold both with respect to the $\mathrm{C}$ and $\mathrm{D}$ groups. On the contrary, total $\mathrm{T}_{3}$ and $\mathrm{FT}_{3}$ concentrations did not increase with the infusion of $T_{4}$, and were as low as in $\mathrm{D}$ dams. The infusion of $\mathrm{T}_{4}$ into the $D$ rats did not alter their very low circulating TSH. In the $T_{4}$-infused diabetic animals, the concentration of $T_{4}$ in the maternal tissues increased as compared to that of $\mathrm{D}$ dams. Normal concentrations were reached in most tissues, with higher than normal levels being reached in liver and mammary tissue. As already observed for circulating $T_{3}$, the concentration of $T_{3}$ in most tissues did not improve with the infusion of $T_{4}$, with $T_{3}$ concentrations in the heart being actually lower than those of $\mathrm{D}$ dams.

$5^{\prime} \mathrm{D}-\mathrm{I}$ activity in the liver and lung was decreased in the diabetic dams (Fig. 4), a finding consistent with the decreased hepatic and pulmonary thyroid hormone concentrations. Despite the decreased plasma $T_{4}$ concentrations, no significant change was observed in the $5^{\prime} \mathrm{D}$-II activity of the cortex, a finding consistent with the lack of decrease in cerebral $\mathrm{T}_{4}$ concentration. Treatment with insulin normalized liver and lung $5^{\prime} \mathrm{D}-\mathrm{I}$ activities. On the contrary, the mean $5^{\prime} \mathrm{D}$-II activity in the maternal cortex decreased with insulin treatment, but the difference with respect to both $\mathrm{D}$ and $\mathrm{C}$ dams was not statistically significant. With

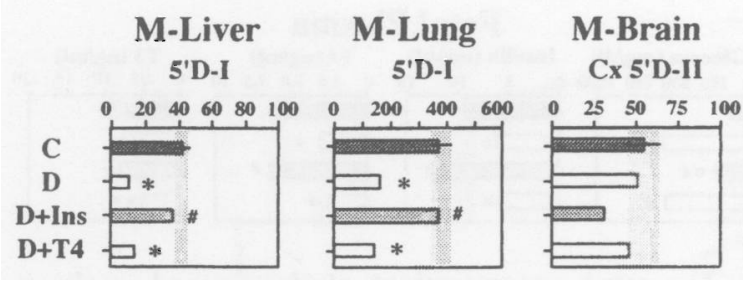

FIG. 4. The activity of the outer-ring $5^{\prime} \mathrm{D}$-deiodinases are shown: type I for liver (pmol $\mathrm{I}^{-} / \mathrm{min} / \mathrm{mg}$ protein) and lung (fmol $\mathrm{I}^{-} / \mathrm{h} / \mathrm{mg}$ protein) and type II for $\mathrm{Cx}$ (fmol $\mathrm{I}^{-} / \mathrm{h} / \mathrm{mg}$ protein). The meaning of the shaded areas, asterisk, and \# is the same as in the legend to Figure 1.

$\mathrm{T}_{4}$ treatment the activities of liver and lung $5^{\prime} \mathrm{D}-\mathrm{I}$ and of cortex $5^{\prime} \mathrm{D}$-II were the same as those of $\mathrm{D}$ animals.

\section{Effects on thyroid hormone status of the placenta}

Figure 5 shows the concentrations of $T_{4}, T_{3}$, and $\mathrm{rT}_{3}$ in the M- and F-placenta. As described for these iodothyronines in the M-plasma, their concentrations decreased in the D dams, and improved with insulin treatment, although $C$ levels were not always reached.

Treatment of the $\mathrm{D}$ dams with $\mathrm{T}_{4}$ increased the concentrations of $T_{4}$ and $r T_{3}$ to normal values in the F-placenta, whereas $T_{3}$ remained as low as in $D$ dams. These changes were similar to those observed in the M-plasma. On the contrary in the $\mathrm{M}$-placenta, $\mathrm{T}_{\mathbf{4}}$ and $\mathrm{rT}_{3}$ levels did not reach normal values and were lower than expected from the changes in M-plasma $T_{4}$ and $r T_{3}$ values, whereas $T_{3}$ was normal and higher than expected from the changes in $M$ plasma $T_{3}$.

\section{Effects in the fetus}

Figure 6 shows the glucose and insulin concentrations in F-plasma, as well as the corresponding $T_{4}$ and $T_{3}$ concentrations. F-plasma glucose was markedly elevated, and insulin decreased, in the $\mathrm{D}$ progeny. Both were clearly ameliorated by treatment of the mothers with insulin, whereas the infusion of $\mathrm{T}_{4}$ had no effect.

The concentrations of $T_{4}$ and $T_{3}$ in the fetal circulation were decreased in the $D$ group, with $T_{4}$ returning to nor-

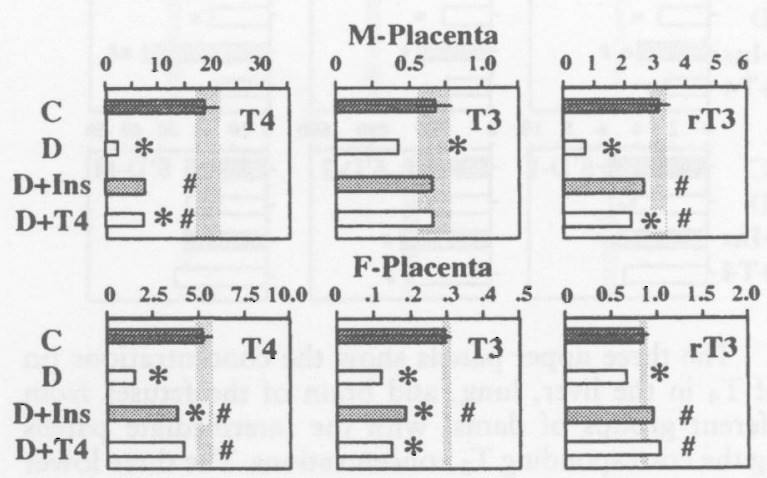

FIG. 5. The concentrations of $T_{4}, T_{3}$, and $\mathrm{rT}_{3}$ in the maternal and fetal placenta are shown for the different groups of dams in $\mathrm{ng} / \mathrm{g}$. The meaning of the shaded areas, asterisk, and \# is the same as indicated in the legend to Figure 1. 


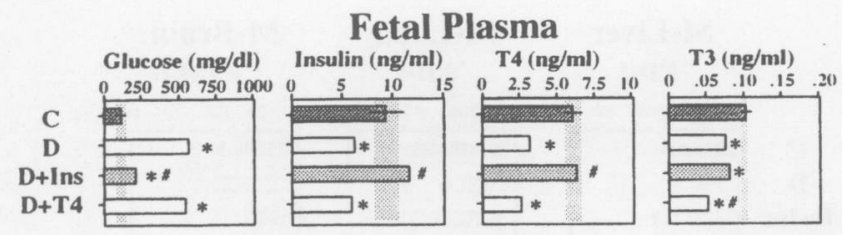

FIG. 6. The mean concentrations of glucose and insulin in the fetal circulation are shown, as well as the $T_{4}$ and $T_{3}$ levels. The meaning of the shaded areas, asterisk, and \# is the same as indicated in the legend to Figure 1.

mal fetal values with insulin treatment of the mothers. Treatment of the $\mathrm{D}$ dams with $\mathrm{T}_{4}$ did not improve fetal $\mathrm{T}_{4}$ concentrations and $T_{3}$ levels were actually lower than those of $\mathrm{D}$ fetuses.

The concentrations of $T_{4}$ and $T_{3}$ in different F-tissues were decreased in the D group (Fig. 7). Treatment of the mothers with insulin usually resulted in improved $\mathrm{T}_{4}$ and $\mathrm{T}_{3}$ concentrations in most F-tissues, as compared to $\mathrm{D}$ fetuses, whereas infusion of $\mathrm{T}_{4}$ into the $\mathrm{D}$ dams did not improve the low $\mathrm{T}_{4}$ and $\mathrm{T}_{3}$ concentrations of $\mathrm{T}$-tissues, with the exception of a modest increase of $\mathrm{F}$-brain $\mathrm{T}_{4}$.

The $5^{\prime} \mathrm{D}$ activity in F-liver and F-lung was slightly decreased as compared to $\mathrm{C}$ fetuses (Fig. 7), being restored to normal both with insulin and $\mathrm{T}_{4}$ treatment of the mothers. 5'D-II activity in the F-brain remained unchanged.

\section{Comparison of the changes in thyroid hormone} status observed in the dams and in their fetuses

Changes in thyroid hormone status of the fetuses from the $\mathrm{D}$ and insulin-treated dams were qualitatively similar to those observed for their mothers: the concentrations of $\mathrm{T}_{4}$ and $\mathrm{T}_{3}$ decreased in the circulation and in tissues, and

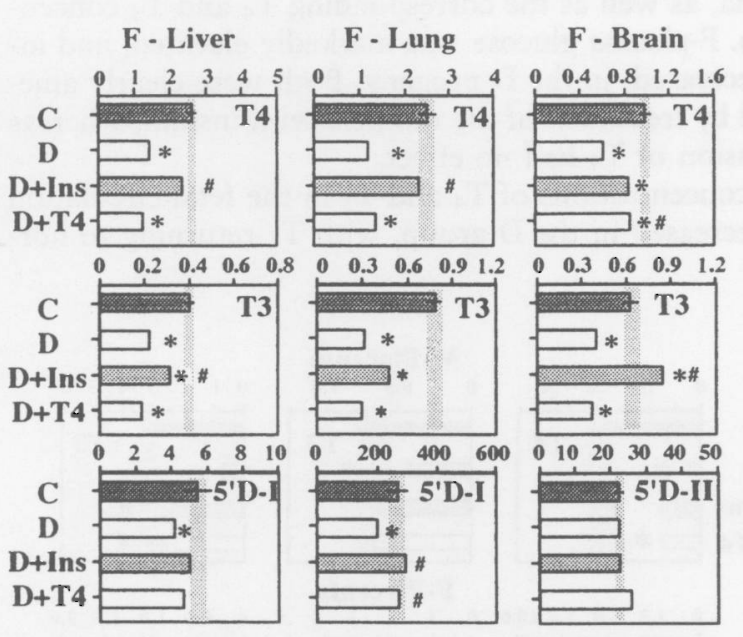

FIG. 7. The three upper panels show the concentrations (in $\mathrm{ng} / \mathrm{g}$ ) of $\mathrm{T}_{4}$ in the liver, lung, and brain of the fetuses from the different groups of dams, with the intermediate panels showing the corresponding $\mathrm{T}_{3}$ concentrations. The three lower panels show the activity of the outer-ring $5^{\prime} \mathrm{D}$, type $I$ for liver (pmol $\mathrm{I}^{-} / \mathrm{min} / \mathrm{mg}$ protein) and lung (fmol $\mathrm{I}^{-} / \mathrm{h} / \mathrm{mg}$ protein), and of type II for $\mathrm{Cx}$ (fmol $\mathrm{I}^{-} / \mathrm{h} / \mathrm{mg}$ protein). The meaning of the shaded areas, asterisk, and \# is the same as indicated in the legend to Figure 1. were clearly improved when the mother was treated with insulin. On the contrary, in fetuses from the $T_{4}$-treated $D$ dams, the changes were different from those observed in the $T_{4}$ and $T_{3}$ concentrations of the mothers. Whereas in the mothers plasma and tissues $T_{4}$ were normal, or higher than normal, the concentrations of $\mathrm{T}_{4}$ in plasma and most tissues of their fetuses are as low as in those of fetuses from $\mathrm{D}$ dams, or even lower (i.e., F-plasma $\mathrm{T}_{3}$, Fig. 6). In this respect, the changes of the concentrations of $T_{4}$ in the fetuses from $\mathrm{D}+\mathrm{T}_{4}$ dams were similar to those observed for $\mathrm{T}_{4}$ levels in the M-placenta.

There were very good correlations between indices of the fetal and the maternal diabetic state, as assessed both from the circulating glucose and the insulin concentrations. The F-BW (Table 1) was also affected by the diabetic condition of the mothers, an effect that was ameliorated, but not totally corrected, by the administration of insulin to the $\mathrm{D}$ mothers. On the contrary, treatment with $\mathrm{T}_{4}$ resulted in even smaller fetuses than those of $\mathrm{D}$ mothers. The $\mathrm{F}-\mathrm{BW}$ appeared to be related to other indices of the outcome of pregnancy, such as the number of viable fetuses per litter $(n=24 ; r=0.66 ; p<0.001)$.

\section{DISCUSSION}

\section{Effects of STZ-induced diabetes mellitus and $T_{4}$ treatment on the mother}

Alterations in thyroid hormone status have been extensively described for nonpregnant adult rats, treated with STZ to induce diabetes mellitus. These are considered typical of the alterations of thyroid function and thyroid hormone metabolism observed in "nonthyroidal illness" $(5,6,10)$. At present they are considered as beneficial adaptive responses in situations of limited availability of intracellular energy, when a decrease in $\mathrm{T}_{3}$-dependent catabolic effects is desirable $(5-7,26)$, although this idea is being reconsidered (26). The two best known mechanisms involved in these responses are a decreased thyroidal secretion of both $T_{4}$ and $T_{3}$, which would lower the pool of $T_{4}$ available for extrathyroidal generation of $T_{3}$, and a decrease in the activity of enzymes involved in the extrathyroidal generation of $T_{3}$ from $T_{4}$.

The sequence of events leading to the first of these mechanisms appears to involve decreased release of hypothalamic TRH (27-29), decreased secretion of TSH $(27-28,30-33)$, and a decreased sensitivity of the thyroid to TSH (32). The normal feedback mechanism is superseded, and TSH levels actually decrease, despite the lower levels of circulating total and/or free $\mathrm{T}_{4}$ and $\mathrm{T}_{3}$. Indeed, a return to normal secretion of TSH, accompanied by normalization of the thyroidal release of hormones, is considered as an index that the illness is remitting, or that the metabolic alterations are under control. In the nonpregnant rat with STZ-induced diabetes mellitus these mechanisms are fully operative, and the decreased thyroidal production of the iodothyronines is quantitative very important (10).

In the present study diabetes mellitus was induced during pregnancy. The changes in circulating total and free $T_{4}$ and $T_{3}$, together with decreased $T S H$, and the low $T_{4}$ and 
$T_{3}$ levels found in all the tissues studied in the present $D$ dams are in agreement with the changes described for the nonpregnant diabetic rats (10), and for patients dying from different nonthyroidal illnesses (34), indicating that 2 weeks after the injection of STZ, the adaptive mechanisms involving decreased thyroidal secretion of thyroid hormones are fully operative.

With respect to the second mechanism, the direct measure of $5^{\prime} \mathrm{D}-\mathrm{I}$ activities in the liver and lung of the pregnant $\mathrm{D}$ rats of the present study has confirmed that generation of $T_{3}$ from $T_{4}$ is decreased. Such a decrease was also previously described for both nonpregnant $(9,35,36)$ and pregnant (11) diabetic rats, as well as a decreased expression of $5^{\prime} \mathrm{D}$-I mRNA (35). In contrast, in agreement with results in nonpregnant diabetic rats (37), 5'D-II activity in the cerebral cortex of the pregnant $D$ rats was not changed. In other experimental situations not involving diabetes, however, a decrease in circulating $T_{4}$ is accompanied by an increase in $5^{\prime} \mathrm{D}$-II activity of the cortex. This response was not observed in the $\mathrm{D}$ dams, possibly because cerebral $\mathrm{T}_{4}$ was not decreased.

Although treatment with $T_{3}$ has been recently found to be beneficial after coronary artery bypass surgery $(38,39)$, it is suspected that treatment with $\mathrm{T}_{4}$ is of no benefit to patients with nonthyroidal illness $(40,41)$. Even so, we had not foreseen that treatment of the $\mathrm{D}$ dams with $\mathrm{T}_{4}$ would actually markedly worsen their condition. Their circulating insulin levels were actually lower than those of D dams. They clearly lost more body weight, and the outcome of their pregnancy was very poor; their litters were the smallest, both as regards the number and weight of the fetuses, and the number of resorptions the greatest. This deterioration could be explained if the administration of $T_{4}$, in a dose sufficient to compensate for the decreased thyroidal secretion of hormone, increased the amount of substrate available to $5^{\prime} \mathrm{D}-\mathrm{I}$, and more $\mathrm{T}_{3}$ might be generated as compared to that of $\mathrm{D}$ dams, despite the decreased activity of the enzyme. The ensuing increase of the extrathyroidal $T_{3}$ pool would then be expected to aggravate $T_{3}$-dependent catabolic events, further decreasing the availability of intracellular energy (41).

This possible explanation is not, however, supported by present findings, as there was no evidence whatsoever that the $T_{3}$ pools increased: $T_{3}$ concentrations in plasma and tissues were actually as low as in D dams, or even lower (i.e., heart $\mathrm{T}_{3}$ levels). This was an unexpected finding that suggests several possible explanations. More $T_{3}$ might actually have been generated and its deiodination increased, the steady state levels of $T_{3}$ remaining the same. $T_{4}$ may be having a catabolic effect per se, either through nonnuclear mechanism(s) of action, or by binding to nuclear receptors, which are not saturated by $\mathrm{T}_{3}$ because of the decreased availability of $T_{3}$. Further experiments are necessary to clarify this unexpected effect of the infusion of $\mathrm{T}_{4}$ into $\mathrm{D}$ dams.

\section{Effects of STZ-induced maternal diabetes mellitus and $T_{4}$ treatment on the fetus}

Present results confirm and extend our preliminary observations on the effects of maternal STZ-induced diabetes mellitus on fetal thyroid hormone status, as studied at 20 $\mathrm{dg}$ (11). The observed alterations in fetal thyroid hormone status are likely to result from the altered carbohydrate metabolism of their mothers, and from the ensuing alteration of carbohydrate metabolism in the fetus, and not from a direct destructive action of the STZ on the fetal pancreas. Maternal hyperglycemia results in overstimulation and finally exhaustion of the fetal pancreas (42). When maternal hyperglycemia is corrected with insulin treatment, fetal glycemia and insulinemia become normal. Considering that the placenta is impermeable to maternal insulin (43), normalization of fetal insulinemia indicates that the fetal pancreas had not been damaged by the injection of STZ to their mothers.

The thyroid hormone concentrations were lower in plasma and tissues that were obtained from fetuses of $D$ dams, most of these alterations improving when the maternal (and fetal) hyperglycemia improved with insulin treatment of the mother. Despite the fact that treatment of the dams with $\mathrm{T}_{4}$ ensured a normal maternal thyroxinemia, with $\mathrm{FT}_{4}$ concentrations being actually increased, $\mathrm{T}_{4}$ concentrations in the $\mathrm{M}$ - and F-placenta were not normal, although higher than in the placentas from $D$ dams. In fetal plasma and tissues, $T_{4}$ concentrations were as low as in fetuses from $\mathrm{D}$ dams, except for a slight increase in the F-brain, which did not, however, reach normal concentrations. These findings contrast with those obtained in other models of maternal-fetal hypothyroxinemia caused by primary thyroid failure (1). The same dose of $T_{4}$ as used for the present study, when infused into MMl-treated dams, clearly increased the concentrations of $\mathrm{T}_{4}$ in the $\mathrm{M}$ - and F-placenta, as well as in F-plasma and F-tissues, above those of MMI fetuses from untreated dams. Maintenance of normal $\mathrm{T}_{4}$ levels of the MMl-treated dams ensured normal $\mathrm{T}_{3}$ concentrations in the fetal brain (1). Two main factors were implied in this protective effect of maternal $T_{4}$, namely, a relatively minor increase in the amount of $T_{4}$ available to the fetal brain, and a marked increase in cerebral 5'D-II activity. No such beneficial effects resulted from the correction of the maternal hypothyroxinemia by treatment of $\mathrm{D}$ dams with $\mathrm{T}_{4}$. Treatment of the $\mathrm{D}$ dams with $\mathrm{T}_{4}$ did not improve the concentrations of $\mathrm{T}_{3}$ either in the F-plasma or F-tissues, the brain included, despite the small increase in F-brain $\mathrm{T}_{4}$. The lack of ameliorating effects on F-brain $\mathrm{T}_{3}$ might be explained by the observed lack of response of $5^{\prime} \mathrm{D}$-II activity in the F-brain of the D fetuses. Moreover, the infusion of $\mathrm{T}_{4}$ into the $\mathrm{D}$ dams had clear negative effects on the degree of illness of the mothers, and on the general development of the litter and individual fetuses.

Unfortunately, the present results suggest that prevention of the maternal hypothyroxinemia, which would be relatively easy to accomplish, would be of little benefit, and might actually be harmful for the development of the fetus. Adequate control of the diabetes mellitus appears to be of prime importance.

\section{CONCLUSIONS}

Present results show that maternal diabetes mellitus, and possibly maternal nonthyroidal illnesses compromising intracellular energy availability, results in severe impairment 
of the thyroid hormone status of the fetus. This includes low cerebral concentrations of $T_{3}$ during a very critical period of brain development. Although maternal diabetes as a cause of maternal hypothyroxinemia would be easily recognized, and controlled with insulin, other causes of maternal hypothyroxinemia might not always be evident, or might not be promptly controlled. Correction of the maternal hypothyroxinemia by treatment with $\mathrm{T}_{4}$ might be attempted to protect the fetal brain (1). Unfortunately, the present results indicate that in such cases prevention of the maternal hypothyroxinemia might be of little benefit. If the present results are relevant for man and for causes of maternal hypothyroxinemia other than maternal diabetes, it would appear that correction of the illness is necessary to protect the brain, as compensatory mechanisms usually involved in maintaining cerebral $\mathrm{T}_{3}$ homeostasis might not be operative, and correction of maternal hypothyroxinemia, without adequate control of the illness is of no benefit, and might actually be harmful. It would appear advisable to take the present tentative conclusions into consideration when faced with maternal hypothyroxinemia caused by nonthyroid illness, and not by primary thyroid failure.

\section{ACKNOWLEDGMENTS}

We are grateful to S. Durán, A. Hernández, and M.J. Presas for invaluable technical assistance, and to Dr. J. Schröder-van der Elst and Prof. D. van der Heide (The Netherlands) for their helpful comments and discussions. This work was supported by Grant FISS (Fondo de Investigaciones Sanitarias) 92/0888, Spain.

\section{REFERENCES}

1. Calvo RM, Obregón MJ, Escobar del Rey F, Morreale de Escobar G 1990 Congenital hypothyroidism, as studied in rats. Crucial role of thyroxine but not of triiodothyronine in the protection of the fetal brain. J Clin Invest 86:889-899.

2. Ruiz de Oña C, Obregón MJ, Escobar del Rey F, Morreale de Escobar G 1988 Developmental changes in rat brain 5'deiodinase and thyroid hormones during the fetal period. The effects of fetal hypothyroidism and maternal thyroid hormones. Pediat Res 24:588-594.

3. Obregón MJ, Ruiz de Oña C, Calvo RM, Escobar del Rey F, Morreale de Escobar G 1991 Outer ring iodothyronine deiodinases and thyroid hormone economy: Responses to iodine deficiency in the rat fetus and neonate. Endocrinology 129:2663-2673.

4. Pharoah POD, Ellis SM, Ekins RP, Williams ES 1976 Maternal thyroid function, iodine deficiency and fetal development. Clin Endocrinol (London) 5:159-166.

5. Wartofsky L, Burman KD 1982. Alterations in thyroid function in patients with systemic illness: The "euthyroid sick syndrome”. Endocrine Rev 3:164-217.

6. Kaptein EM 1990 Abnormal thyroid function test in euthyroid persons. In: Becker KL (ed) Principles and Practice of Endocrinology and Metabolism. J.B. Lippincot, Philadelphia, pp 293-300.

7. Tibaldi JM, Surks MI 1985 Animal models of non-thyroidal disease. Endocr Rev 6:87-101.
8. Pittman CA, Suda AK, Chambers JB, McDaniel HG, Ray GY 1979 Abnormalities of thyroid turnover in patients with diabetes mellitus before and after insulin therapy. J Clin Endocrinol Metab 48:854-860.

9. Chopra IJ, Wiersinga W, Frank H 1981 Alterations in hepatic monodeiodination of iodothyronines in the diabetic rat. Life Sci 28:1765-1776.

10. Schröeder van der Elst JP, van der Heide D 1992 Effects of streptozotocin-induced diabetes and food restriction on quantities and source of $\mathrm{T} 4$ and $\mathrm{T} 3$ in rat tissues. Diabetes 41:147-152.

11. Calvo R, Obregón MJ, Escobar del Rey F, Morreale de Escobar G 1991 The effects of maternal diabetes mellitus on thyroid hormone economy of rat fetuses. In: Gordon A, Gross J, Henneman G (eds) Progress in Thyroid Research. Balkema, Rotterdam, pp 813-816.

12. Herrera E, Palacín M, Martín A, Lasunción MA 1985 Relationship between maternal and fetal fuels and placental glucose transfer in rats with maternal diabetes of varying severity. Diabetes 34 (Suppl. 2):42-46.

13. Calvo R, Obregón MJ, Escobar del Rey F, Morreale de Escobar G 1992 The rat placenta and the transfer of thyroid hormones from the mother to the fetus. Effects of maternal thyroid status. Endocrinology 131:367-365.

14. Obregón MJ, Morreale de Escobar G, Escobar del Rey F 1978 Concentrations of triiodo-L-thyronine in the plasma and tissues of normal rats as determined by radioimmunoassay: Comparison with results obtained by an isotopic equilibrium technique. Endocrinology 103:2145-2153.

15. Morreale de Escobar G, Pastor R, Obregón MJ, Escobar del Rey F 1985 Effects of maternal hypothyroidism on the weight and thyroid hormone content of rat embryonic tissues, before and after onset of fetal thyroid function. Endocrinology 117:1890-1900.

16. Morreale de Escobar G, Calvo R, Escobar del Rey F, Obregón MJ 1994 Thyroid hormones in tissues from fetal and adult rats. Endocrinology 134:2410-2415.

17. Ruiz de Oña C, Morreale de Escobar G, Calvo R, Escobar del Rey F, Obregón MJ 1991 Thyroid hormones and 5'-deiodinase in the rat fetus late in gestation: Effects of maternal hypothyroidism. Endocrinology 128:422-432.

18. Mendel CM, Laughton CW, McMahon FA, Cavalieri RR 1991 Inability to detect an inhibitor of thyroxine-serum protein binding in sera from patients with non-thyroidal illness. Metabolism 40:491-502.

19. Obregón MJ, Ruiz de Oña C, Hernández A, Calvo R, Escobar del Rey F, Morreale de Escobar G 1989 Thyroid hormones and 5 '-dediodinase in rat brown adipose tissue during fetal life. Am J Physiol 257:E625-631.

20. Lowry OH, Rosebrough NJ, Farr AL, Randall RJ 1951 Protein measurement with the Folin phenol reagent. J Biol Chem 193:265-275.

21. Calvo R, Obregón MJ, Ruiz de Oña C, Ferreiro B, Escobar del Rey F, Morreale de Escobar G 1990 Thyroid hormone economy in pregnant rats near term. A "physiological" animal model of non-thyroidal illness? Endocrinology 127:10-16.

22. Hugget ASG, Nixon DA 1957 Use of glucose oxidase, peroxidase and o-dianisidine in determination of blood and urinary glucose. Lancet 1:368-370.

23. Morreale de Escobar G, Calvo R, Escobar de Rey F, Obregón MJ 1993 Differential effects of thyroid hormones on growth and thyrotropic hormone in rat fetuses near term. Endocrinology 132:2056-2064.

24. Weeke J, Orskov H 1973 Synthesis of monolabeled 3,5,3'- 
triiodothyronine and thyroxine of maximum specific activity for radioimmunoassay. Scand J Clin Lab Invest 32:357-360.

25. Snedecor GW, Cochran WG 1980 Statistical Methods, ed 7. Iowa State University Press, Ames, IA.

26. Utiger RD 1995 Altered thyroid function in nonthyroidal illness and surgery. To treat or not to treat? $N$ Engl J Med 23:1562-1563.

27. González C, Montoya E, Jolin T 1980 Effect of streptozotocin diabetes on the hypothalamic-pituitary-thyroid axis in the rat. Endocrinology 107:2099-2103.

28. Wilber JF, Banerji A, Prasad C, Mori C 1981 Alterations in hypothalamic pituitary-thyroid regulation produced by diabetes mellitus. Life Sci 28:1757-1763.

29. Rondeel JMM, de Greef WJ, Heide R, Visser TJ $1992 \mathrm{Hy}$ pothalamo-hypophysial-thyroid axis in streptozotocin-induced diabetes. Endocrinology 130:216-220.

30. Pericás I, Jolín T 1977 The effect of streptozotocin-induced diabetes on the pituitary-thryoid axis in goitrogen-treated rats. Acta Endocrinol (Copenh) 86:128-139.

31. Jolín T, González C 1978 Thyroid iodine metabolism in streptozotocin diabetic rats. Acta Endocrinol (Copenh) 88:506-516.

32. Pastor R, Jolin T 1983 Peripheral metabolism and secretion rate of thyrotropin in STZ-diabetic rats. Endocrinology 112:1454-1459.

33. Ortíz-Caro J, González C, Jolín T 1984 Diurnal variations of plasma growth hormone, thyrotropin, thyroxine and triiodothyronine in streptozotocin-diabetic and food restricted rats. Endocrinology 115:2227-2232.

34. Arem R, Wiener GJ, Kaplan SG, Kim HS, Reichlin S, Kaplan MM 1993 Reduced tissue thyroid hormone levels in fatal illness. Metabolism 42:1102-1108.

35. O'Mara BA, W. Dittrich W, Lauterio TJ, StGermain DL 1993 Pretranslational regulation of type 15 '-deiodinase by thyroid hormones and in fasted and diabetic rats. Endocrinology 133:1715-1723.

36. Gavin LA, McMahon FA, Mueller M 1981 The mechanism of impaired T3 production from T4 in diabetes. Diabetes 30:694-699.

37. Gavin LA, Cavalieri RR 1986 Iodothyronine deiodination in the brain of diabetic rats: Influence of thyroid status. J Endocrinol Invest 9:127-133.

38. Novitzky D, Cooper DKC, Swanepoel A 1989 Inotropic effect of triiodothyronine (T3) in low cardiac output following cardioplegic arrest and cardiopulmonary bypass: An initial experience in patients undergoing open heart surgery. Eur J Cardiothorac Surg 3:140-145.

39. Klemperer JD, Klein I, Gomez M, Helm RE, Ojamaa K, Thomas SJ, Isom OW, Krieger K 1995 Thyroid hormone treatment after coronary-artery bypass surgery. $\mathrm{N}$ Engl J Med 23:1522-1527.

40. Brent G, Hershman JM 1986 Thyroxine therapy in patients with severe non thyroidal illnesses and low thyroxine concentrations. J Clin Endocrinol Metab 63:1-8.

41. Gardner DF, Kaplan MM, Stanley CA, Utiger RD 1979 Effect of triiodothyronine replacement of the metabolic and pituitary responses to starvation. N Engl J Med 300:579-584.

42. Aerts L, van Assche FA 1977 Rat fetal endocrine pancreas in experimental diabetes. J Endocrinol 73:339-346.

43. Knobil E, Yosimovich JB 1958 Placental transfer of thyrotropic hormone, thyroxine, triiodothyronine and insulin. Ann NY Acad Sci 75:895-904.

Address reprint requests to: Dr. M. J. Obregón Instituto de Investigaciones Biomédicas Arturo Duperier 4 28029-Madrid, Spain 
This article has been cited by:

1. Ruchi Sharma, Jyotdeep Kaur, Akhtar Mahmood. 2009. Effect of Maternal Diabetes on Postnatal Development of Brush Border Enzymes and Transport Functions in Rat Intestine. Journal of Pediatric Gastroenterology and Nutrition 49:1, 8-15. [CrossRef]

2. A Pascual-Leone. 2003. Age-dependent adaptation of the liver thyroid status and recovery of serum levels and hepatic insulinlike growth factor-I expression in neonatal and adult diabetic rats. Metabolism 52:9, 1117-1125. [CrossRef]

3. Nikolaos Stathatos, Claresa Levetan, Kenneth D. Burman, Leonard Wartofsky. 2001. The controversy of the treatment of critically ill patients with thyroid hormone. Best Practice \& Research Clinical Endocrinology \& Metabolism 15:4, 465-478. [CrossRef]

4. Rosa Maria Calvo, Rosa Forcen, Maria Jesus Obregon, Francisco Escobar Del Rey, Gabriella Morreale De Escobar, Javier Regadera. 1998. Immunohistochemical and morphometric studies of the fetal pancreas in diabetic pregnant rats. Effects of insulin administration. The Anatomical Record 251:2, 173-180. [CrossRef] 